Article

\title{
Degradation of Reactive Brilliant Red X-3B by Photo-Fenton-like Process: Effects of Water Chemistry Factors and Degradation Mechanism
}

\author{
Gong Cheng ${ }^{1,2,3}$, Jing Wan ${ }^{1}$, Qin Li ${ }^{3}$, Lei Sun ${ }^{1}$, Yibo Zhang ${ }^{1}$, Zhang Li ${ }^{1}$, Chenyuan Dang ${ }^{1}$ and Jie Fu ${ }^{1}$,*(D) \\ 1 School of Environmental Science and Engineering, Huazhong University of Science and Technology, \\ Wuhan 430074, China; chenggong021@163.com (G.C.); m202073912@hust.edu.cn (J.W.); \\ sunlei0701@gmail.com (L.S.); ybo_zhang@sina.com (Y.Z.); lizhang01357@163.com (Z.L.); \\ dangcy@hust.edu.cn (C.D.) \\ 2 Shenzhen Academy of Environmental Sciences, Shenzhen 518001, China \\ 3 Engineering Research Center for Cleaner Production of Textile Dyeing and Printing, Ministry of Education, \\ Wuhan Textile University, Wuhan 430073, China; liqinliqin2022@163.com \\ * Correspondence: jiefu@hust.edu.cn
}

check for

updates

Citation: Cheng, G.; Wan, J.; Li, Q.;

Sun, L.; Zhang, Y.; Li, Z.; Dang, C.; Fu, J. Degradation of Reactive Brilliant Red X-3B by Photo-Fenton-like Process: Effects of Water Chemistry Factors and Degradation Mechanism. Water 2022, 14, 380. https://doi.org/ $10.3390 / \mathrm{w} 14030380$

Academic Editors: Jiangyong Hu, Say Leong Ong, Wenjun Sun and Weiling Sun

Received: 5 January 2022

Accepted: 19 January 2022

Published: 27 January 2022

Publisher's Note: MDPI stays neutral with regard to jurisdictional claims in published maps and institutional affiliations.

Copyright: () 2022 by the authors Licensee MDPI, Basel, Switzerland. This article is an open access article distributed under the terms and conditions of the Creative Commons Attribution (CC BY) license (https:// creativecommons.org/licenses/by/ $4.0 /)$.

\begin{abstract}
Azo dye wastewater belongs to the highly concentrated organic wastewater, which is difficult to be treated by traditional biological processes. The oxidation efficiency of a single physicochemical method is not considerable. Recent research indicated that the advanced oxidation processes (AOPs) based on the highly reactive hydroxyl radical $(\cdot \mathrm{OH})$ became one of the preferred methods in dealing with such dye wastewater. In this paper, the typical azo dye, reactive brilliant red X-3B, was employed as the target pollutant, and the transition metal $\mathrm{Mn}$ and hydrogen peroxide as the catalysts. A photo-Fenton-like process, $\mathrm{UV} / \mathrm{Mn}^{2+}-\mathrm{H}_{2} \mathrm{O}_{2}$ system, was established, which enables a combination of various technologies to improve azo dye degradation efficiency while reducing disposal costs. The results indicated that the $\mathrm{UV} / \mathrm{Mn}^{2+}-\mathrm{H}_{2} \mathrm{O}_{2}$ system had the synergism of $\mathrm{Mn}^{2+} / \mathrm{H}_{2} \mathrm{O}_{2}$ and $\mathrm{UV} / \mathrm{H}_{2} \mathrm{O}_{2}$, which was 2.6 times greater than the sum of the two individual effects. And the degradation of X-3B reached the optimum under the conditions of $0.59 \mathrm{mmol} / \mathrm{L}$ of the $\mathrm{Mn}^{2+}, 10 \mathrm{mmol} / \mathrm{L}$ of the $\mathrm{H}_{2} \mathrm{O}_{2}, \mathrm{pH}$ $=6$ and a high level of $\mathrm{DO}$. The $\cdot \mathrm{OH}$, generated from chem-catalytic and photocatalytic decomposition of $\mathrm{H}_{2} \mathrm{O}_{2}$, played the predominant role in the decolorization of $\mathrm{X}-3 \mathrm{~B}$ and mineralization of its intermediates. The $\cdot \mathrm{OH}$ tended to attack and break the chromophore group, resulting in the rapid decolorization of X-3B. The azo bond in $\mathrm{X}-3 \mathrm{~B}$ was easy to be decomposed in the form of $\mathrm{N}_{2}$, while the triazinyl group was recalcitrant for ring opening. The degradation process of the UV $/ \mathrm{Mn}^{2+}-\mathrm{H}_{2} \mathrm{O}_{2}$ system preferred to be conducted at an acidic condition and appropriate concentrations of $\mathrm{Mn}^{2+}$ and $\mathrm{H}_{2} \mathrm{O}_{2}$. The alkaline condition would decrease the utilization of $\mathrm{H}_{2} \mathrm{O}_{2}$, and excessive $\mathrm{H}_{2} \mathrm{O}_{2}$ would also quench the $\cdot \mathrm{OH}$.
\end{abstract}

Keywords: photo-Fenton-like process; $\mathrm{UV} / \mathrm{Mn}^{2+}-\mathrm{H}_{2} \mathrm{O}_{2}$ system; reactive brilliant red X-3B; advanced oxidation processes; hydroxyl radical

\section{Introduction}

Azo dyes, as the most used type of commercial dyes, are widely applied in various fields, including textile, printing, leather, paint, plastics, and food processing [1,2]. Reactive brilliant red $\mathrm{X}-3 \mathrm{~B}$ is an indispensable azo dye in the roll dyeing, dip dyeing and tiedyeing of cotton and viscose fibers, as well as the dyeing of polyester-cotton and polyestercotton blended fabrics, and accounts for more than $60 \%$ of total dyes [3,4], which is very representative. The discharge of large amounts of dye pollutants into water bodies will threaten the aquatic organisms and human health [5]. The presence of dyes in the natural aquatic ecosystem will prevent light penetration and oxygen transfer into water, resulting in the reduction of the dissolved oxygen (DO) levels, and increases of the chemical oxygen 
demand (COD) and biochemical oxygen demand (BOD) levels in water sources $[5,6]$. Furthermore, the metabolic cleavage of azo linkage during degradation produces toxic byproducts, which are carcinogenic to both human beings and aquatic life $[4,7]$. Therefore, effective treatment of textile effluents is crucial prior to their ultimate discharge to the environment [5].

With the continuous progress and widespread use of dye synthesis technology, the treatment of printing and dyeing wastewater has become more difficult. Printing and dyeing wastewater discharge standards are becoming more and more stringent, and the existing treatment facilities have difficulties to meet the requirements of printing and dyeing wastewater discharge standards [8]. Seeking an efficient and economical method for treating dye wastewater and minimizing the discharge of wastewater and pollutants has become an urgent problem to be solved in the dye manufacturing industry and the printing and dyeing industry, which has attracted the attention of a wide range of scholars $[9,10]$. There are many techniques that have been developed to deal with the dye wastewater including physical, chemical and biological methods, such as ultrasound irradiation [11], photocatalytic processes [7], coagulation-flocculation [12], adsorption [13], electrochemical oxidation [14], and biodegradation [15]. At present, the treatment methods for various dye wastewater at home and abroad are mainly biochemical methods, supplemented by chemical methods or physicochemical methods. Nevertheless, due to the low removal rates of COD and color by biochemical methods, the post-treatment of physical methods is relatively low and prone to produce the secondary pollution; and the chemical method has the disadvantage of high cost as an effective way to improve the efficiency of sewage treatment. As a powerful and environmentally friendly approach, advanced oxidation processes (AOPs), have received attention for treating recalcitrant dye wastewater, by generating highly reactive transient species (i.e., $\cdot \mathrm{OH}$ ) in situ to achieve high removal efficiency and total mineralization of dye molecules $[10,16]$.

Among various AOPs for the treatment of printing and dyeing wastewater, $\mathrm{H}_{2} \mathrm{O}_{2}$ as a commonly used oxidant has a higher oxidation potential, which can react with metal ions to produce highly active $\cdot \mathrm{OH}$. The $\cdot \mathrm{OH}$ involved in AOPs is a kind of nonspecific oxidant that can oxidize and mineralize almost all the organic molecules owing to its high oxidation potential $\left(\mathrm{E}^{\circ}=+2.8 \mathrm{eV}\right)[17,18]$. The $\mathrm{H}_{2} \mathrm{O}_{2}$ is often used in combination with $\mathrm{Fe}^{2+}$ to comprise of the Fenton process, which proves to be an efficient, inexpensive, and green technology for the treatment of wastewaters containing a variety of toxic substances $[19,20]$. In addition, the light irradiation can promote the generation of $\cdot \mathrm{OH}$ and degradation of organic matter in the Fenton system, and therefore, some studies have attempted the application of the UV/Fenton (photo-Fenton) system to the treatment of printing and dyeing wastewater [21,22].

Nevertheless, $\mathrm{Fe}^{2+}\left(\mathrm{Fe}^{3+}\right)$, as a catalyst in the Fenton and photo-Fenton processes in homogeneous media, must be used in an acidic environment $(\mathrm{pH}<3)$, which requires high corrosion resistance of the equipment and greatly reduces the promotion of applications. A large amount of sludge containing Fe ions is produced after the wastewater treatment. Moreover, the utilization rate of $\mathrm{H}_{2} \mathrm{O}_{2}$ is not ideal. Many problems need to be solved for the application of the Fenton process in wastewater treatment [23]. Fortunately, in recent years, many studies have found that the oxidizability of Fenton-like $\left(\mathrm{Fe}^{3+} / \mathrm{H}_{2} \mathrm{O}_{2}\right)$ oxidation system can be effectively improved under the action of $\mathrm{Ce}^{3+}$ and $\mathrm{Mn}^{2+}[24,25]$. The $\mathrm{Ce}^{3+}$ and $\mathrm{Mn}^{2+}$ enhanced Fenton-like oxidation system has a stronger oxidation ability and higher reagent utilization rate. The catalytic oxidation method using transition metals as catalysts has a high removal rate of COD and color, and can even oxidize most of the soluble dyes [24]. Compared with the original Fenton-like oxidation system, it has shown good prospects for development [25]. In short, although there are many methods for the treatment of dye wastewater, each has its own limitations, which makes it difficult to achieve the unity of the removal effect, economic cost and ecological protection. The application of the multi-stage combined degradation method is more advantageous, and 
it is expected to effectively reduce the chroma and ensure the effluent without increasing costs to meet emission standards.

Currently, little is known about the synergistic effects produced by the combination of UV / Fenton and Fenton-like systems. In this context, the reactive brilliant red X-3B was used to simulate dye wastewater, and the removal efficiency and degradation effects of different degradation systems were compared including $\mathrm{Mn}^{2+}, \mathrm{H}_{2} \mathrm{O}_{2}, \mathrm{UV} / \mathrm{Mn}^{2+}, \mathrm{Mn}^{2+} / \mathrm{H}_{2} \mathrm{O}_{2}$, $\mathrm{UV} / \mathrm{H}_{2} \mathrm{O}_{2}$, and $\mathrm{UV} / \mathrm{Mn}^{2+}-\mathrm{H}_{2} \mathrm{O}_{2}$. The synergistic and degradation mechanisms of the $\mathrm{UV} / \mathrm{Mn}^{2+}-\mathrm{H}_{2} \mathrm{O}_{2}$ system were preliminarily investigated. The effects of $\mathrm{Mn}^{2+}$ and $\mathrm{H}_{2} \mathrm{O}_{2}$ concentration, initial solution $\mathrm{pH}$, and $\mathrm{X}-3 \mathrm{~B}$ initial dosage on the degradation of $\mathrm{X}-3 \mathrm{~B}$ by the UV/ $/ \mathrm{Mn}^{2+}-\mathrm{H}_{2} \mathrm{O}_{2}$ process were comprehensively investigated. The research on this combined process is expected to effectively improve the degradation efficiency of azo dyes and reduce the treatment cost, and provide important information for the research on the operating conditions and mechanism of the process, which can provide some references for its application and promotion.

\section{Materials and Methods}

\subsection{Preparation and Testing of Dye Wastewater}

The commercial azo dye X-3B was used to prepare $1 \mathrm{~L}$ of $150 \mathrm{mg} / \mathrm{L}$ simulated wastewater. The chemical structure and UV-vis absorption spectrum of X-3B are given in Figure 1. $\mathrm{X}-3 \mathrm{~B}$ had five absorption peaks in the 200-800 $\mathrm{nm}$ wavelength range, i.e., $236 \mathrm{~nm}, 285 \mathrm{~nm}$, $329 \mathrm{~nm}, 512 \mathrm{~nm}$, and $538 \mathrm{~nm}$. According to the theory of organic spectroscopy [26,27] and the chemical structure of X-3B, it could be seen that: $236 \mathrm{~nm}$ and $285 \mathrm{~nm}$ were the characteristic absorption peaks of the benzene ring; $329 \mathrm{~nm}$ was the absorption peak of the naphthalene ring. The azo bond ( $-\mathrm{N}=\mathrm{N}-$ ) is an atomic group containing $\pi$ electrons, which forms a conjugated color system of 8-naphthol-3 with the benzene ring and a 6-disulfonic acid with the naphthalene ring, and the characteristic absorption peaks appeared at $512 \mathrm{~nm}$ and $538 \mathrm{~nm}$, respectively [28]. In this study, $538 \mathrm{~nm}$ was selected as the characteristic absorption peak of X-3B in the UV-vis region, which was represented by $\mathrm{A}_{538}$.
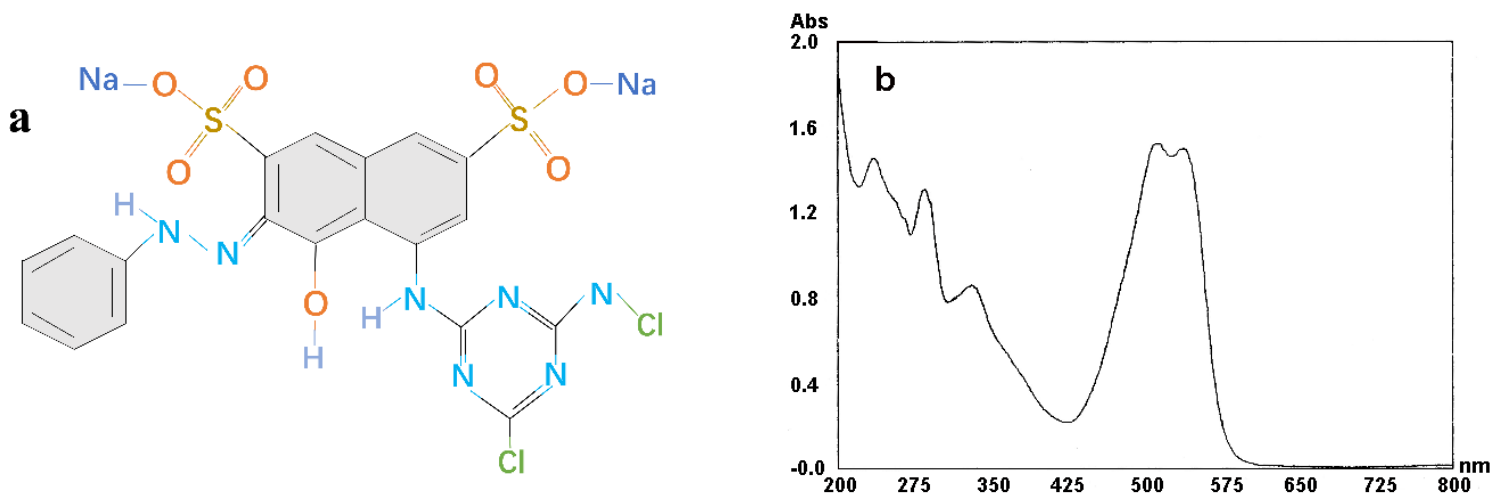

Figure 1. (a) Chemical structure of $\mathrm{X}-3 \mathrm{~B}$, (b) UV-vis absorption spectrum of $\mathrm{X}-3 \mathrm{~B}$.

\subsection{Experimental Apparatus and Procedures}

The schematic diagram of the experimental apparatus is shown in Figure 2. For a typical degradation experiment, a certain concentration of $\mathrm{MnSO}_{4}$ and $\mathrm{H}_{2} \mathrm{O}_{2}$ were added into $\mathrm{X}-3 \mathrm{~B}$ solution in the reactor, and the initial $\mathrm{pH}$ value was adjusted with $20 \% \mathrm{H}_{2} \mathrm{SO}_{4}$ and $10 \% \mathrm{NaOH}$. After sequentially turning on the aerating apparatus and UV lamp, the degradation reaction was started. At a certain interval, solution samples were taken for chemical analyses. 


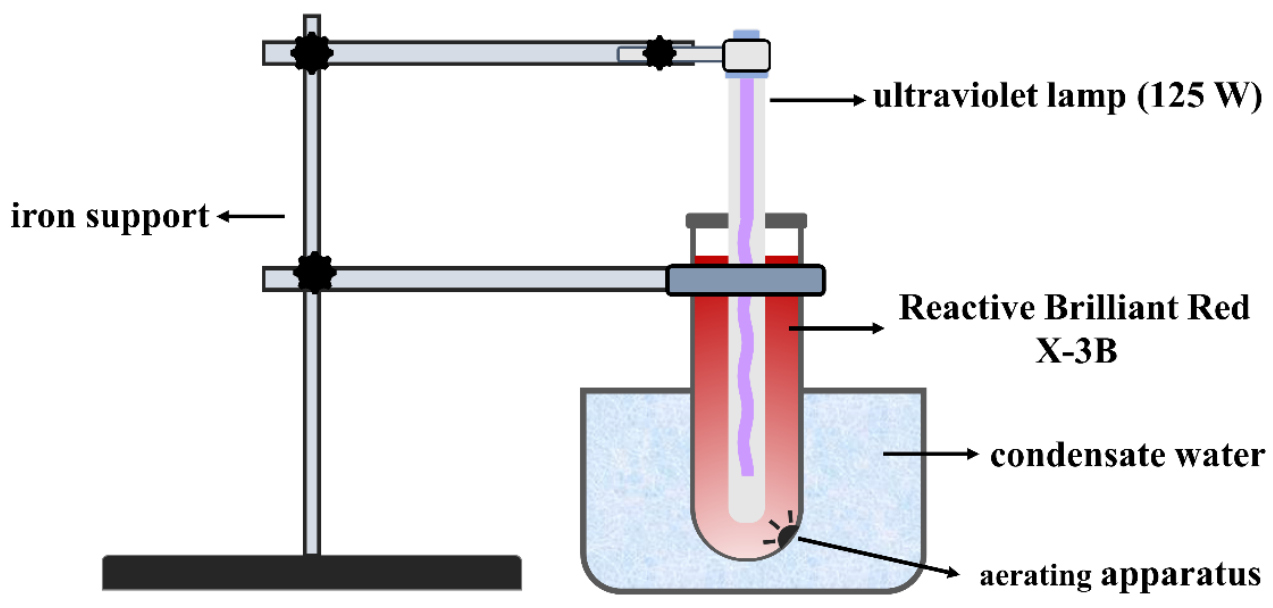

Figure 2. Schematic diagram of experimental apparatus.

For the choice of ideal catalyst, a certain volume of X-3B solution of $50 \mathrm{mg} / \mathrm{L}$ was prepared. The candidate catalysts (i.e., $\mathrm{MnSO}_{4}, \mathrm{MnO}_{2}, \mathrm{CeO}_{2}, \mathrm{CuSO}_{4}$ or $\mathrm{ZnSO}_{4}$ ) of $0.2 \mathrm{~g} / \mathrm{L}$ and $1 \mathrm{~mL} \mathrm{H} \mathrm{H}_{2} \mathrm{O}_{2}$ were added into X-3B solution. The degradation experiments were conducted at room temperature, and the degradation of $\mathrm{X}-3 \mathrm{~B}$ was monitored at $0,30,60,90$ and $120 \mathrm{~min}$, respectively. The comparative results indicated the most ideal catalyst was $\mathrm{MnSO}_{4}$ (see the results section below).

For the comparison of different degradation systems, the degradation experiments were performed with $1 \mathrm{~L} \mathrm{X}-3 \mathrm{~B}$ solution of $150 \mathrm{mg} / \mathrm{L}$. The $\mathrm{Mn}^{2+}$ of $0.6 \mathrm{mmol} / \mathrm{L}$ and $\mathrm{H}_{2} \mathrm{O}_{2}$ of $10 \mathrm{mmol} / \mathrm{L}$ were employed. Different degradation systems including single $\mathrm{Mn}^{2+}$, single $\mathrm{H}_{2} \mathrm{O}_{2}, \mathrm{UV} / \mathrm{Mn}^{2+}, \mathrm{Mn}^{2+} / \mathrm{H}_{2} \mathrm{O}_{2}, \mathrm{UV} / \mathrm{H}_{2} \mathrm{O}_{2}$ and UV $/ \mathrm{Mn}^{2+}-\mathrm{H}_{2} \mathrm{O}_{2}$ were carried out, respectively. Solution samples were withdrawn at $0,10,20,30,40,50$ and $60 \mathrm{~min}$, respectively, and measured the change of $\mathrm{X}-3 \mathrm{~B}$ concentration.

For the effects of various water chemistry factors, the basic experimental conditions were set as: $1 \mathrm{~L}$ of $150 \mathrm{mg} / \mathrm{L} \mathrm{X-3B}, 10 \mathrm{mmol} / \mathrm{L}$ of $\mathrm{H}_{2} \mathrm{O}_{2}, 0.59 \mathrm{mmol} / \mathrm{L}$ of $\mathrm{Mn}^{2+}$, and UV irradiation. The change of $\mathrm{X}-3 \mathrm{~B}$ concentration was measured at $0,10,20,30,40$, 50 and $60 \mathrm{~min}$, respectively. Batch experiments were conducted by changing the initial concentrations of $\mathrm{H}_{2} \mathrm{O}_{2}(5,10$ and $20 \mathrm{mmol} / \mathrm{L}), \mathrm{Mn}^{2+}(0.3,0.59,1.18$ and $2.6 \mathrm{mmol} / \mathrm{L})$ and $\mathrm{X}-3 \mathrm{~B}(100,150,200,250,500$ and $600 \mathrm{mg} / \mathrm{L})$, and initial solution $\mathrm{pH}(2,4,6$ and 8).

For the study of synergistic mechanisms, different doses of methanol (0, 0.24, 0.29 and $0.32 \mathrm{mmol} / \mathrm{L}$ ) were added into $\mathrm{X}-3 \mathrm{~B}$ solution to conduct the degradation experiments with the UV $/ \mathrm{Mn}^{2+}-\mathrm{H}_{2} \mathrm{O}_{2}$ system. After that, the degradation experiments were conducted in the following three scenarios: (1) $1 \mathrm{~L}$ of $150 \mathrm{mg} / \mathrm{L} \mathrm{X-3B}, 10 \mathrm{mmol} / \mathrm{L}$ of $\mathrm{H}_{2} \mathrm{O}_{2}, 0.59 \mathrm{mmol} / \mathrm{L}$ of $\mathrm{Mn}^{2+}$, and UV irradiation; (2) $1 \mathrm{~L}$ of $150 \mathrm{mg} / \mathrm{L} \mathrm{X-3B,} 10 \mathrm{mmol} / \mathrm{L}$ of $\mathrm{H}_{2} \mathrm{O}_{2}, 0 \mathrm{mmol} / \mathrm{L}$ of $\mathrm{Mn}^{2+}$, and UV irradiation; and (3) $1 \mathrm{~L}$ of $150 \mathrm{mg} / \mathrm{L} \mathrm{X-3B,} 10 \mathrm{mmol} / \mathrm{L}$ of $\mathrm{H}_{2} \mathrm{O}_{2}, 0.59 \mathrm{mmol} / \mathrm{L}$ of $\mathrm{Mn}^{2+}$, and without UV irradiation. Solution samples were taken at $0,30,60,90$ and $120 \mathrm{~min}$, respectively, and the residual $\mathrm{H}_{2} \mathrm{O}_{2}$, total organic carbon (TOC) and total nitrogen (TN) were measured.

To investigate the degradation pathway, the changes of UV-vis spectra of $\mathrm{X}-3 \mathrm{~B}$ and anions $\left(\mathrm{Cl}^{-}, \mathrm{NO}_{3}{ }^{-}\right.$and $\left.\mathrm{SO}_{4}{ }^{2-}\right)$ concentrations were recorded during the degradation process of the $\mathrm{UV} / \mathrm{Mn}^{2+}-\mathrm{H}_{2} \mathrm{O}_{2}$ system.

\subsection{Analytical Methods}

For the measurements of UV-vis absorption spectra and the concentration of X-3B, an UV-1201 UV-vis spectrophotometer (Beijing Ruili Analytical Instrument Co., Ltd., Beijing, China) was used with scanning wavelength range of $200-800 \mathrm{~nm}$. The pathlength of quartz cuvette was $1 \mathrm{~cm}$, and distilled water was used as a reference. A 538 was employed for the quantitative analysis of X-3B. The TOC and TN were determined by a Multi N/C TOC/TN analyzer (Jena Analytical Instruments Co., Ltd., Thuringia, Germany). For the measure- 
ment of residual $\mathrm{H}_{2} \mathrm{O}_{2}$, ammonium molybdate spectrophotometry was employed using $2.4 \mathrm{mmol} / \mathrm{L}$ ammonium molybdate and absorbance at $350 \mathrm{~nm}$. The ion chromatographic analyzer ICS-900 (Dionex, Sunnyvale, CA, USA), equipped with Ion Pac AS23 ion separation column, DS5 conductivity detector and MMS300 suppressor, was used to analyze the concentration of $\mathrm{Cl}^{-}, \mathrm{NO}_{3}{ }^{-}$, and $\mathrm{SO}_{4}{ }^{2-}$ during the degradation reactions. The sample injection volume was $10 \mu \mathrm{L}$, and $\mathrm{KOH}$ solution was employed as the eluent with a flow rate of $1.0 \mathrm{~mL} / \mathrm{min}$. Before the measurement, the sample was diluted, decolorized using On Guard P type pretreatment column, and filtered through a $0.45 \mu \mathrm{m}$ filter membrane.

\section{Results and Discussion}

\subsection{Decolorization of $\mathrm{X}-3 \mathrm{~B}$ by $\mathrm{H}_{2} \mathrm{O}_{2}$ with Different Catalysts}

The decolorization rates of $\mathrm{X}-3 \mathrm{~B}$ by $\mathrm{H}_{2} \mathrm{O}_{2}$ with different catalysts showed great difference (Figure 3). In the catalytic degradation experiments, the order of the ability of these five catalysts to decompose $\mathrm{H}_{2} \mathrm{O}_{2}$ is: $\mathrm{CuSO}_{4}>\mathrm{MnO}_{2}>\mathrm{MnSO}_{4}>\mathrm{CeO}_{2}>\mathrm{ZnSO}_{4}$, respectively. Among these five catalysts, $\mathrm{Cu}, \mathrm{Mn}$, and $\mathrm{Zn}$ belong to transition metal elements, while Ce belongs to rare earth elements. The experimental results showed that the catalytic performance of $\mathrm{CeO}_{2}$ was not very obvious. $\mathrm{CuSO}_{4}$ has the highest catalytic activity, which is consistent with the results of other studies [29]. The catalytic activities of $\mathrm{MnSO}_{4}$ and $\mathrm{MnO}_{2}$ are similar, affording $\sim 25 \%$ of decolorization rate of X-3B after 120 min reaction. Previous studies have shown that $\mathrm{Mn}^{2+}$ has good catalytic performance in homogeneous catalytic ozonation reactions, and $\mathrm{MnO}_{2}$ also has strong heterogeneous catalytic performance $[30,31]$. However, red-brown flocs appeared in the solution with $\mathrm{CuSO}_{4}$, and the powdery $\mathrm{MnO}_{2}$ was insoluble in water, which would interfere with the measurements of the water chemistry parameters. The catalytic activity of $\mathrm{ZnSO}_{4}$ was the worst, probably because $\mathrm{Zn}^{2+}$ has no variable valence state, so it can be considered that $\mathrm{ZnSO}_{4}$ has no catalytic activity for the catalytic decomposition of $\mathrm{H}_{2} \mathrm{O}_{2}$. Therefore, $\mathrm{MnSO}_{4}$ was finally selected as the ideal catalyst for further investigations.

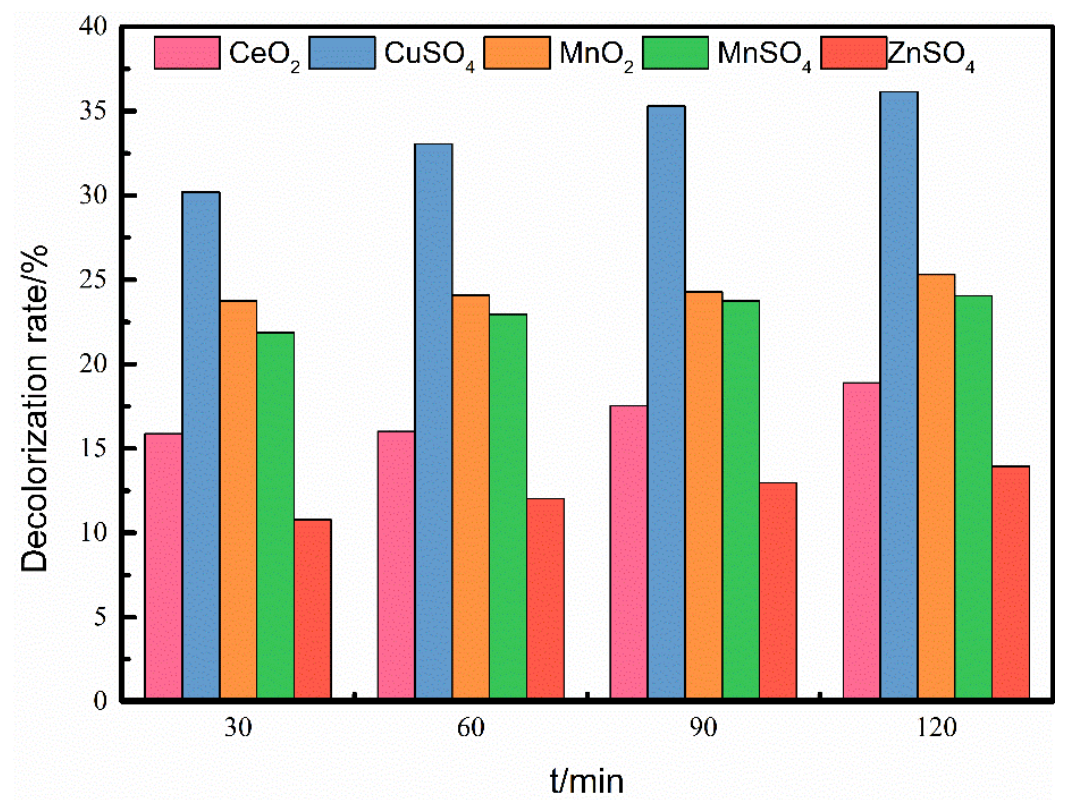

Figure 3. Decolorization of $\mathrm{X}-3 \mathrm{~B}$ by $\mathrm{H}_{2} \mathrm{O}_{2}$ with different catalysts.

\subsection{Degradation of $X-3 B$ in Different Systems}

The removal efficiencies of $\mathrm{X}-3 \mathrm{~B}$ by $\mathrm{Mn}^{2+}, \mathrm{H}_{2} \mathrm{O}_{2}, \mathrm{UV} / \mathrm{Mn}^{2+}, \mathrm{Mn}^{2+} / \mathrm{H}_{2} \mathrm{O}_{2}, \mathrm{UV} / \mathrm{H}_{2} \mathrm{O}_{2}$, and $\mathrm{UV} / \mathrm{Mn}^{2+}-\mathrm{H}_{2} \mathrm{O}_{2}$ are presented in Figure 4. According to the experimental results, the degradation rates of $\mathrm{X}-3 \mathrm{~B}$ in these systems can be summarized as: $\mathrm{UV} / \mathrm{Mn}^{2+}-\mathrm{H}_{2} \mathrm{O}_{2}$ $>\mathrm{UV} / \mathrm{H}_{2} \mathrm{O}_{2}>\mathrm{Mn}^{2+} / \mathrm{H}_{2} \mathrm{O}_{2}>\mathrm{H}_{2} \mathrm{O}_{2}>\mathrm{UV}>\mathrm{Mn}^{2+}$. It can be seen that X-3B was stable under the catalysis of $\mathrm{Mn}^{2+}$ alone or $\mathrm{H}_{2} \mathrm{O}_{2}$ alone, indicating that $\mathrm{Mn}^{2+}$ cannot directly 
degrade $\mathrm{X}-3 \mathrm{~B}$, and the catalytic oxidation effect was not obvious even under the action of UV photolysis. It can be assumed that X-3B cannot be directly degraded by these single processes. However, when $\mathrm{Mn}^{2+}$ and $\mathrm{H}_{2} \mathrm{O}_{2}$ coexist, the degradation effect of X-3B appears, which indicates that the catalysis of $\mathrm{Mn}^{2+}$ is crucial for the oxidation of hydrogen peroxide.

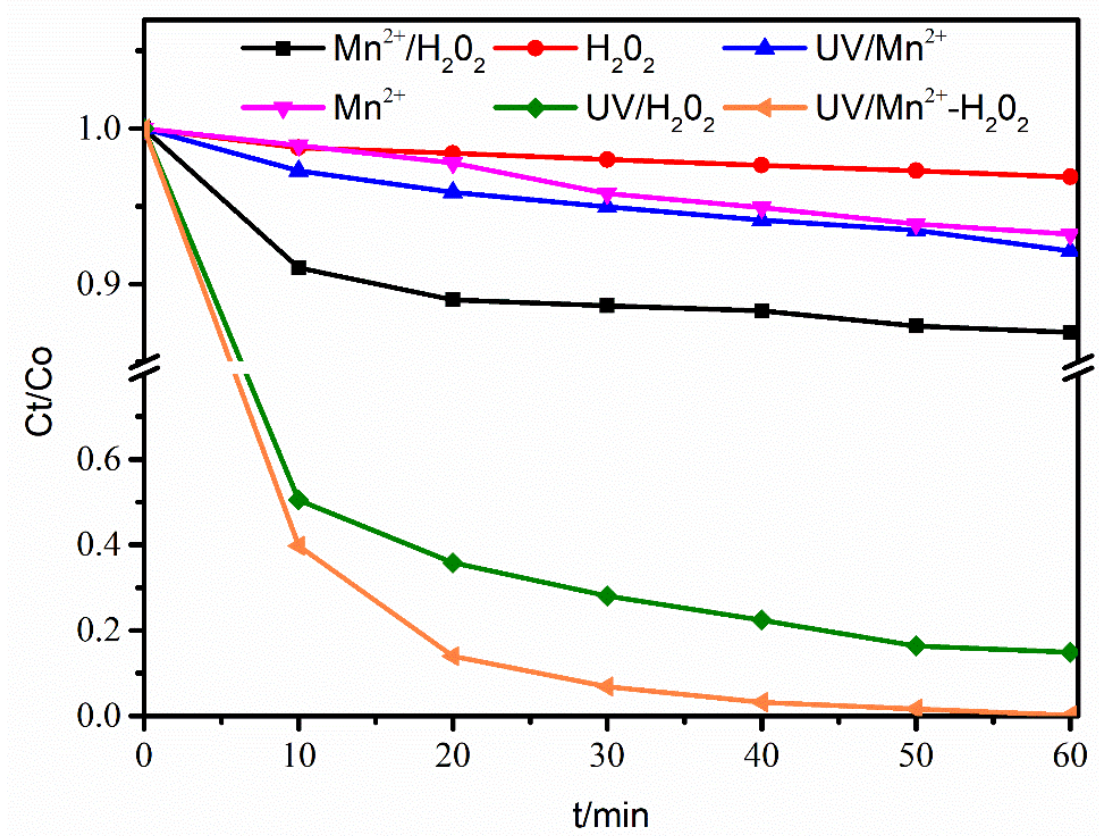

Figure 4. Degradation of X-3B in different systems.

For the combined systems, i.e., $\mathrm{Mn}^{2+} / \mathrm{H}_{2} \mathrm{O}_{2}, \mathrm{UV} / \mathrm{H}_{2} \mathrm{O}_{2}$ and $\mathrm{UV} / \mathrm{Mn}^{2+}-\mathrm{H}_{2} \mathrm{O}_{2}$, the degradation kinetics of $\mathrm{X}-3 \mathrm{~B}$ was fitted by the first-order kinetic equation [32]. The calculated apparent reaction rate constant $\left(k_{\mathrm{app}}\right)$ for $\mathrm{UV} / \mathrm{Mn}^{2+}-\mathrm{H}_{2} \mathrm{O}_{2}, \mathrm{UV} / \mathrm{H}_{2} \mathrm{O}_{2}$, and $\mathrm{Mn}^{2+} / \mathrm{H}_{2} \mathrm{O}_{2}$ was $0.0951,0.0368$ and $0.0030 \mathrm{~min}^{-1}$, respectively. It can be seen that X-3B was degraded the fastest in $\mathrm{UV} / \mathrm{Mn}^{2+}-\mathrm{H}_{2} \mathrm{O}_{2}$ system, and the $k_{\text {app }}$ is 2.6 times the sum of the other two systems. It is feasible to draw the conclusion that the synergistic effect of photocatalysis and $\mathrm{Mn}^{2+}$ catalysis is crucial to improve the degradation ability of the $\mathrm{UV} / \mathrm{Mn}^{2+}-\mathrm{H}_{2} \mathrm{O}_{2}$ system.

\subsection{Factors Affecting the Degradation System of $U V / \mathrm{Mn}^{2+}-\mathrm{H}_{2} \mathrm{O}_{2}$}

\subsubsection{Effects of $\mathrm{Mn}^{2+}$ and $\mathrm{H}_{2} \mathrm{O}_{2}$ Concentrations}

$\mathrm{Mn}^{2+}$, as a catalyst for the $\mathrm{UV} / \mathrm{Mn}^{2+}-\mathrm{H}_{2} \mathrm{O}_{2}$ reaction system, is a necessary factor for generating $\cdot \mathrm{OH}$. As shown in Figure 5a, increasing the concentration of $\mathrm{Mn}^{2+}$ from 0.3 to $0.59 \mathrm{mmol} / \mathrm{L}$ accelerated the decomposition of $\mathrm{H}_{2} \mathrm{O}_{2}$. However, continuously increasing the $\mathrm{Mn}^{2+}$ concentration resulted in an inhibition on the degradation of X-3B. $\mathrm{Mn}^{2+}$ participates in the Fenton-like reaction [24]. An obvious acceleration in the decomposition rate of $\mathrm{H}_{2} \mathrm{O}_{2}$ was observed by adding $\mathrm{Mn}^{2+}$, and a large amount of $\cdot \mathrm{OH}$ was produced. When the dosage of $\mathrm{Mn}^{2+}$ was too high, $\cdot \mathrm{OH}$ would be produced in a very short time and many of them would be consumed by side reactions, which is not conducive to the effective use of $\cdot \mathrm{OH}$. Therefore, the optimal concentration of $\mathrm{Mn}^{2+}$ was determined to be $0.59 \mathrm{mmol} / \mathrm{L}$. 

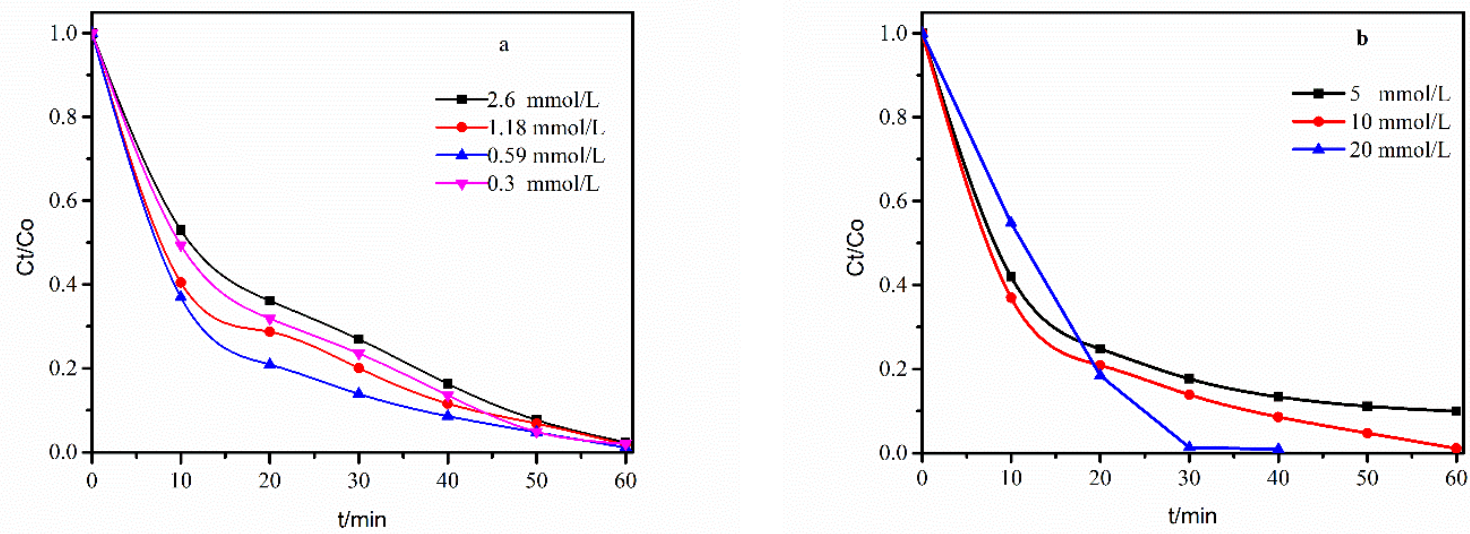

Figure 5. Effects of concentrations of $\mathrm{Mn}^{2+}(\mathbf{a})$ and $\mathrm{H}_{2} \mathrm{O}_{2}(\mathbf{b})$ on the decolorization of X-3B by the $\mathrm{UV} / \mathrm{Mn}^{2+}-\mathrm{H}_{2} \mathrm{O}_{2}$ system.

As an oxidant, the amount of $\mathrm{H}_{2} \mathrm{O}_{2}$ had a great influence on the UV/Mn $\mathrm{Mn}^{2+}-\mathrm{H}_{2} \mathrm{O}_{2}$ degradation system. It can be seen from Figure $5 b$ that the final decolorization rate gradually increased, as the $\mathrm{H}_{2} \mathrm{O}_{2}$ concentration was increased from 5 to $20 \mathrm{mmol} / \mathrm{L}$. However, within the initial $10 \mathrm{~min}$ of the degradation reaction, the degradation rate with $10 \mathrm{mmol} / \mathrm{L} \mathrm{H}_{2} \mathrm{O}_{2}$ was significantly better than that with $20 \mathrm{mmol} / \mathrm{L}$. The $\mathrm{H}_{2} \mathrm{O}_{2}$ can not only produce $\cdot \mathrm{OH}$, but also acts as a radical scavenger in the system [11]. The excessive $\mathrm{H}_{2} \mathrm{O}_{2}$ would consume $\cdot \mathrm{OH}$, leading to the reduction of available $\cdot \mathrm{OH}$ for the oxidation of $\mathrm{X}-3 \mathrm{~B}$. Considering that excessive $\mathrm{H}_{2} \mathrm{O}_{2}$ will increase the COD in the effluent and increase the treatment cost, the ideal concentration of $\mathrm{H}_{2} \mathrm{O}_{2}$ was determined to be $10 \mathrm{mmol} / \mathrm{L}$.

\subsubsection{Effect of Initial Solution $\mathrm{pH}$}

Figure 6 shows the effects of the initial solution $\mathrm{pH}$ on the $\mathrm{X}-3 \mathrm{~B}$ decolorization rate by the UV $/ \mathrm{Mn}^{2+}-\mathrm{H}_{2} \mathrm{O}_{2}$ system. When the initial condition of the experiment was increased from $\mathrm{pH}=2$ to $\mathrm{pH}=8$, the degradation rate of $\mathrm{X}-3 \mathrm{~B}$ was gradually slowed down, but all could be completely degraded after $60 \mathrm{~min}$. An increase in initial $\mathrm{pH}\left(\mathrm{OH}^{-}\right.$concentration) will decrease the utilization of $\mathrm{H}_{2} \mathrm{O}_{2}$, and reduce $\cdot \mathrm{OH}$ concentration. Under alkaline conditions, $\mathrm{H}_{2} \mathrm{O}_{2}$ would like to decompose into $\mathrm{HO}_{2}{ }^{-}$and $\mathrm{H}_{2} \mathrm{O}$ [33]. On the contrary, $\mathrm{H}_{2} \mathrm{O}_{2}$ is relatively stable under acidic conditions, but can be decomposed by UV light and soluble $\mathrm{Mn}^{2+}$ to generate $\cdot \mathrm{OH}$ [34]. As the reaction progressed, the organic carbon in the solution was continuously converted into inorganic carbon. Under alkaline conditions, inorganic carbon existed in the form of $\mathrm{HCO}_{3}{ }^{-}$or $\mathrm{CO}_{3}{ }^{2-}$, which could react with $\cdot \mathrm{OH}$, and then consume $\cdot \mathrm{OH}$ to reduce the catalytic activity [35]. Furthermore, in order to ensure good dyeing properties of azo dyes, they should be used under acidic or neutral conditions, due to its anionic properties. On the other hand, under alkaline conditions, $\mathrm{Mn}^{2+}$ could hydrolyze and be transformed into precipitation, which will inhibit the reactions and reduce the generation of $\cdot \mathrm{OH}$ [25]. For the comprehensive consideration of the above aspects, the $\mathrm{pH}$ value of 6 was selected in the degradation experiments. 


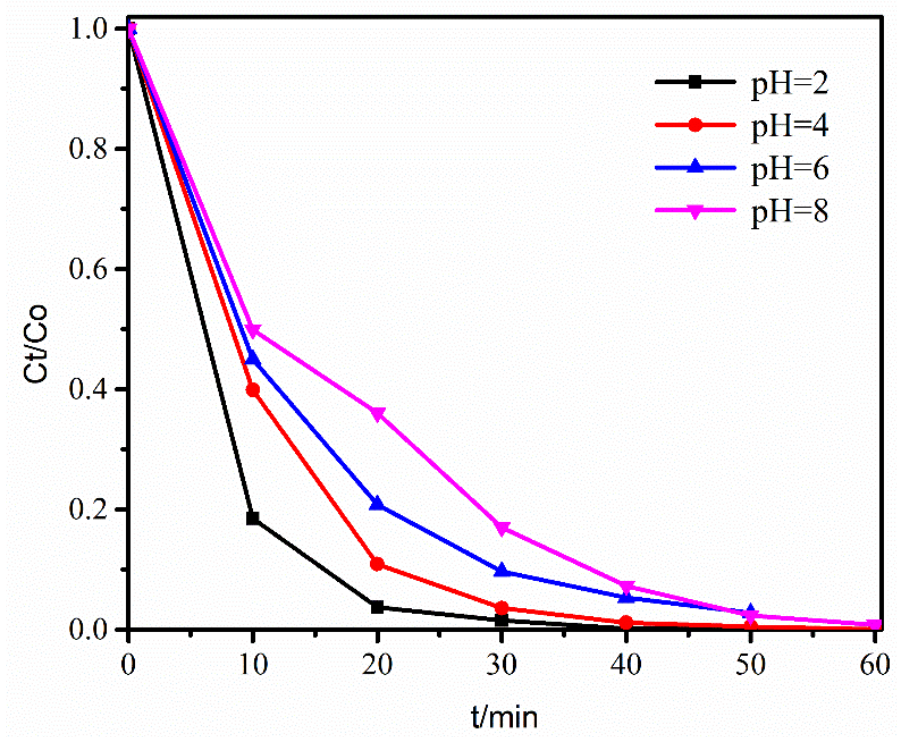

Figure 6. Effect of initial solution $\mathrm{pH}$ value on the decolorization of $\mathrm{X}-3 \mathrm{~B}$ by the $\mathrm{UV} / \mathrm{Mn}^{2+}-\mathrm{H}_{2} \mathrm{O}_{2}$ system.

\subsubsection{Effect of Initial X-3B Concentration}

For different processes, $\mathrm{X}-3 \mathrm{~B}$ concentration in effluent printing and dyeing plants will significantly fluctuate. Therefore, the effect of initial X-3B concentration on X-3B removal efficiency is worth studying. As shown in Figure 7, as the initial concentration increased, $\mathrm{X}-3 \mathrm{~B}$ removal efficiency decreased. The reason is that the dosage of the oxidizing agent was certain, and the amount of $\cdot \mathrm{OH}$ produced was limited [36]. The amount of $\cdot \mathrm{OH}$ used to attack the chromogenic group of $\mathrm{X}-3 \mathrm{~B}$ was not enough to completely break the chromogenic groups, resulting in the decrease of decolorization rate. The light shielding effects caused by excess X-3B may also provide a negative impact for the photo-Fenton-like process [37]. In addition, the increased amount of $\mathrm{X}-3 \mathrm{~B}$ molecules would also produce more intermediates that competed with $\mathrm{X}-3 \mathrm{~B}$ parent molecules for $\cdot \mathrm{OH}[38]$.

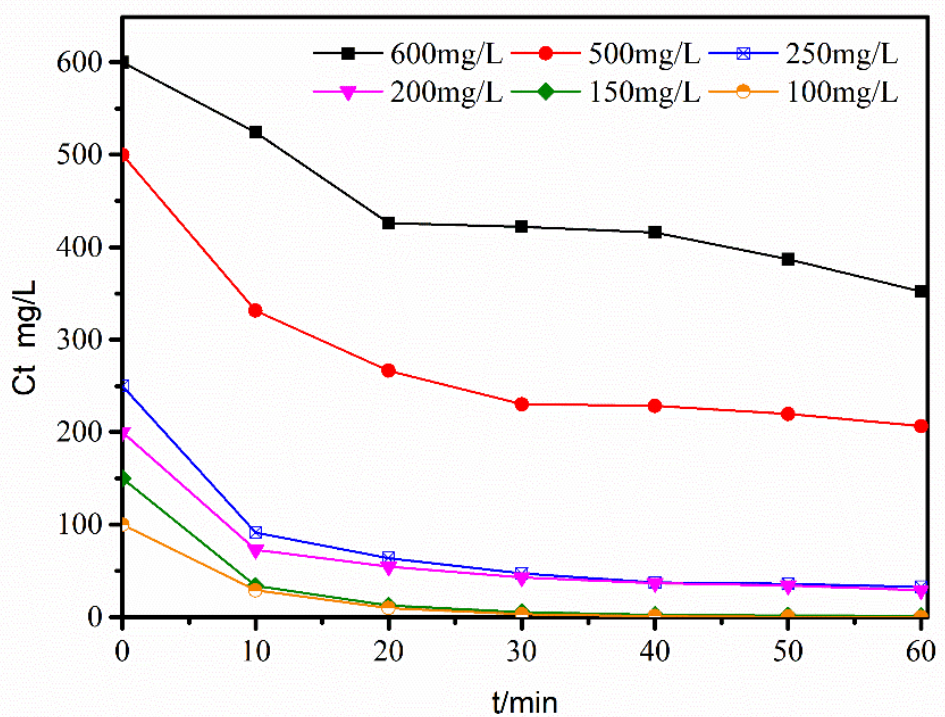

Figure 7. Effect of initial X-3B concentration on the decolorization of X-3B by the UV/Mn ${ }^{2+}-\mathrm{H}_{2} \mathrm{O}_{2}$ system.

\subsection{Role of $\cdot \mathrm{OH}$ in the Degradation System of $\mathrm{UV} / \mathrm{Mn}^{2+}-\mathrm{H}_{2} \mathrm{O}_{2}$}

The $\cdot \mathrm{OH}$ was considered to be the main factor in the degradation of organic pollutants in AOPs [39]. Adding different concentrations of $\cdot \mathrm{OH}$ scavengers could indirectly analyze the change of $\cdot \mathrm{OH}$ in the reaction system, and qualitatively explain the existence and 
contribution of $\cdot \mathrm{OH}$ to the degradation of organic pollutants $[40,41]$. There were many kinds of $\cdot \mathrm{OH}$ scavengers, and alcohols are the most widely used [42,43]. Here, methanol was selected as the $\cdot \mathrm{OH}$ scavenger. As shown in Figure 8 , with the addition of methanol, the degradation rate of $\mathrm{X}-3 \mathrm{~B}$ gradually decreased. With the addition of $0.32 \mathrm{~mol} / \mathrm{L}$ methanol, the degradation of $\mathrm{X}-3 \mathrm{~B}$ was inhibited by $72 \%$. The experimental results indicated that the degradation of $\mathrm{X}-3 \mathrm{~B}$ by the $\mathrm{UV} / \mathrm{Mn}^{2+}-\mathrm{H}_{2} \mathrm{O}_{2}$ system mainly resulted from the oxidation of - $\mathrm{OH}$ [44].

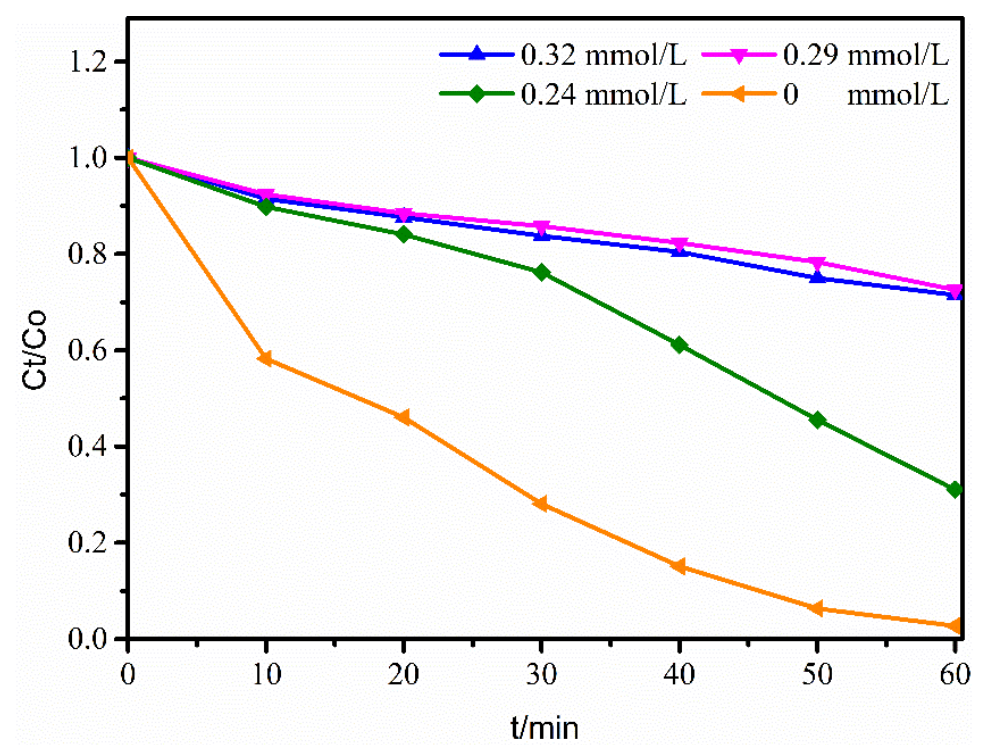

Figure 8. Effect of different concentration methanol additions on the decolorization of X-3B by the $\mathrm{UV} / \mathrm{Mn}^{2+}-\mathrm{H}_{2} \mathrm{O}_{2}$ system.

\subsection{Degradation Mechanism of $\mathrm{UV} / \mathrm{Mn}^{2+}-\mathrm{H}_{2} \mathrm{O}_{2}$ System}

Figure 9 shows the changes of the residual $\mathrm{H}_{2} \mathrm{O}_{2}$ in the three degradation systems of $\mathrm{UV} / \mathrm{H}_{2} \mathrm{O}_{2}, \mathrm{Mn}^{2+} / \mathrm{H}_{2} \mathrm{O}_{2}$ and $\mathrm{UV} / \mathrm{Mn}^{2+}-\mathrm{H}_{2} \mathrm{O}_{2}$ over time. When the reaction time was $60 \mathrm{~min}$, the decomposition of $\mathrm{H}_{2} \mathrm{O}_{2}$ in the three systems was not complete, the residual concentration of $\mathrm{H}_{2} \mathrm{O}_{2}$ was $7.07,8.82$ and $6.18 \mathrm{mmol} / \mathrm{L}$, respectively. When the reaction progressed to $120 \mathrm{~min}$, the residual $\mathrm{H}_{2} \mathrm{O}_{2}(8.47 \mathrm{mmol} / \mathrm{L})$ in the $\mathrm{Mn}^{2+} / \mathrm{H}_{2} \mathrm{O}_{2}$ system did not change significantly, indicating the catalytic effect of single $\mathrm{Mn}^{2+}$ was not remarkable, and the amount of $\cdot \mathrm{OH}$ produced was not enough to oxidize $\mathrm{X}-3 \mathrm{~B} \cdot \mathrm{H}_{2} \mathrm{O}_{2}$ was still excited to form a certain amount of $\cdot \mathrm{OH}$ after $60 \mathrm{~min}$ in the $\mathrm{UV} / \mathrm{H}_{2} \mathrm{O}_{2}$ system, and the residual $\mathrm{H}_{2} \mathrm{O}_{2}$ continuously decreased to $3.7 \mathrm{mmol} / \mathrm{L}$ at $120 \mathrm{~min}$. In the $\mathrm{UV} / \mathrm{Mn}^{2+}-\mathrm{H}_{2} \mathrm{O}_{2}$ system, the residual $\mathrm{H}_{2} \mathrm{O}_{2}$ was the lowest and further decreased to $1.52 \mathrm{mmol} / \mathrm{L}$ at $120 \mathrm{~min}$. These results indicated in the $\mathrm{UV} / \mathrm{Mn}^{2+}-\mathrm{H}_{2} \mathrm{O}_{2}$ system, in addition to UV irradiation, the Fentonlike effect of $\mathrm{Mn}^{2+}$ and $\mathrm{H}_{2} \mathrm{O}_{2}$ was also very important [45]. Under the dual catalysis, $\mathrm{H}_{2} \mathrm{O}_{2}$ decomposed rapidly and produced a large amount of $\cdot \mathrm{OH}$ for the degradation of $\mathrm{X}-3 \mathrm{~B}$. The reaction mechanism is as follows:

$$
\begin{aligned}
\mathrm{Mn}^{2+}+\mathrm{H}_{2} \mathrm{O}_{2} & \rightarrow \mathrm{Mn}^{3+}+\cdot \mathrm{OH}+\mathrm{OH}^{-} \\
\mathrm{H}_{2} \mathrm{O}_{2}+\mathrm{Mn}^{3+}+2 \mathrm{OH}^{-} & \rightarrow \mathrm{Mn}^{2+}+\mathrm{O}_{2}^{-} \cdot+2 \mathrm{H}_{2} \mathrm{O} \\
\mathrm{OH} \cdot+\mathrm{O}_{2}{ }^{-} \cdot & \rightarrow \mathrm{O}_{2}+\mathrm{OH}^{-}
\end{aligned}
$$




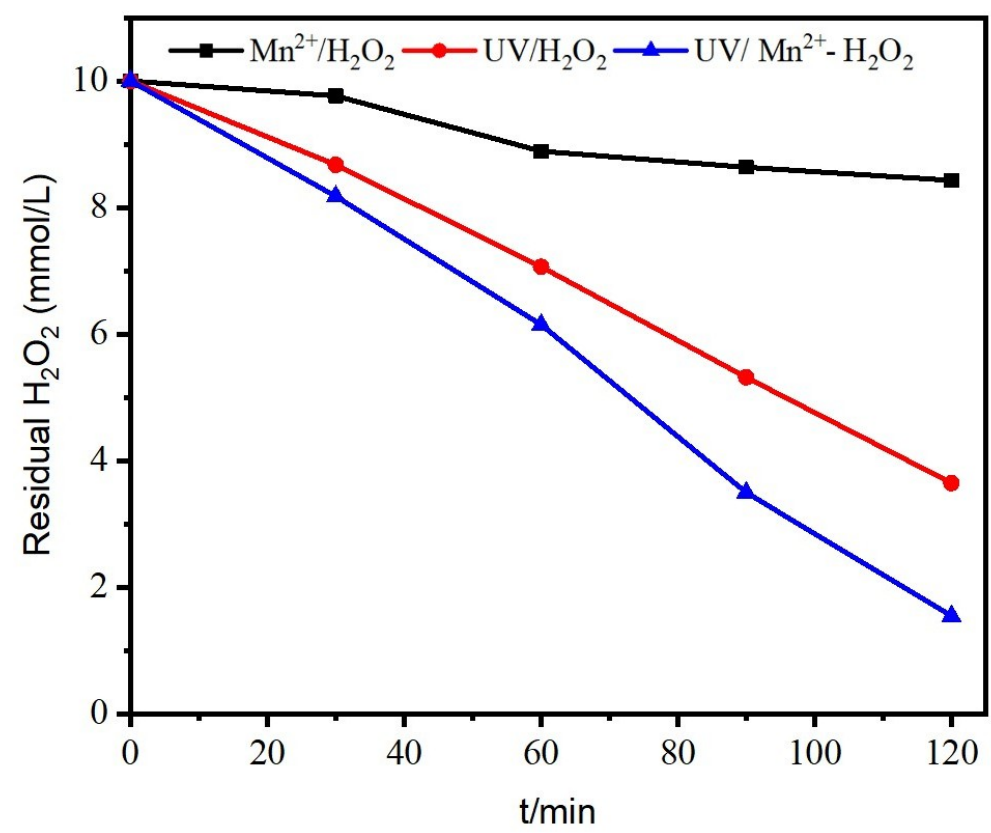

Figure 9. The change of residual $\mathrm{H}_{2} \mathrm{O}_{2}$ during the degradation processes of $\mathrm{X}-3 \mathrm{~B}$ by different systems.

After X-3B was degraded, small molecular nitrides (such as $\mathrm{NO}_{3}{ }^{-}, \mathrm{NO}_{2}{ }^{-}, \mathrm{NH}_{4}{ }^{+}$etc.) would be produced, which could affect the water discharge quality, and TN reflects the total nitrogen content in the solution [46]. As shown in Figure 10a, the removal rate of TN in the two systems of $\mathrm{UV} / \mathrm{H}_{2} \mathrm{O}_{2}$ and $\mathrm{Mn}^{2+} / \mathrm{H}_{2} \mathrm{O}_{2}$ was not ideal, and even the TN content in the solution increased at the beginning of the reaction. The $\mathrm{UV} / \mathrm{Mn}^{2+}-\mathrm{H}_{2} \mathrm{O}_{2}$ system showed a considerable effect for the TN removal, and obtained a TN removal rate of $20.65 \%$ at $120 \mathrm{~min}$.

$\mathbf{a}$

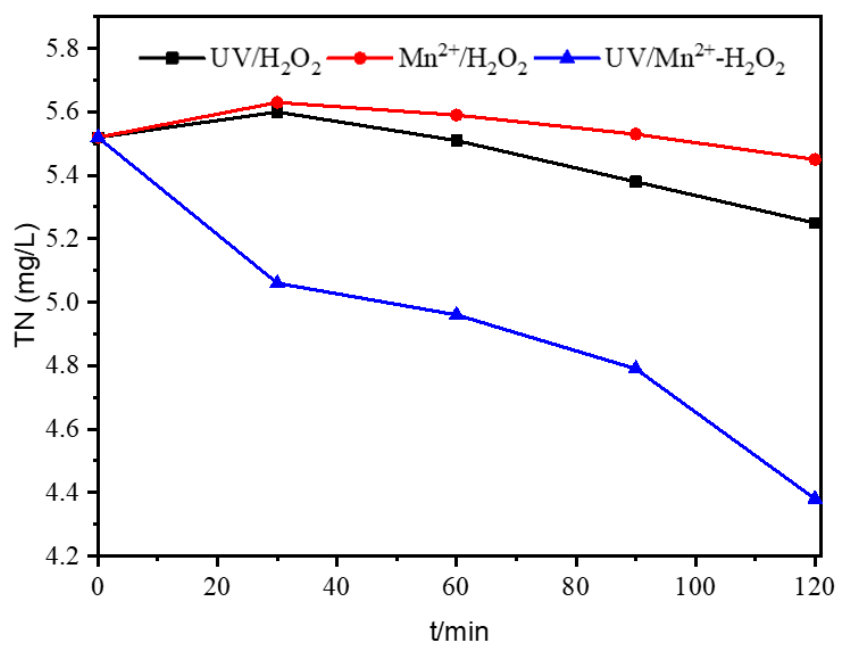

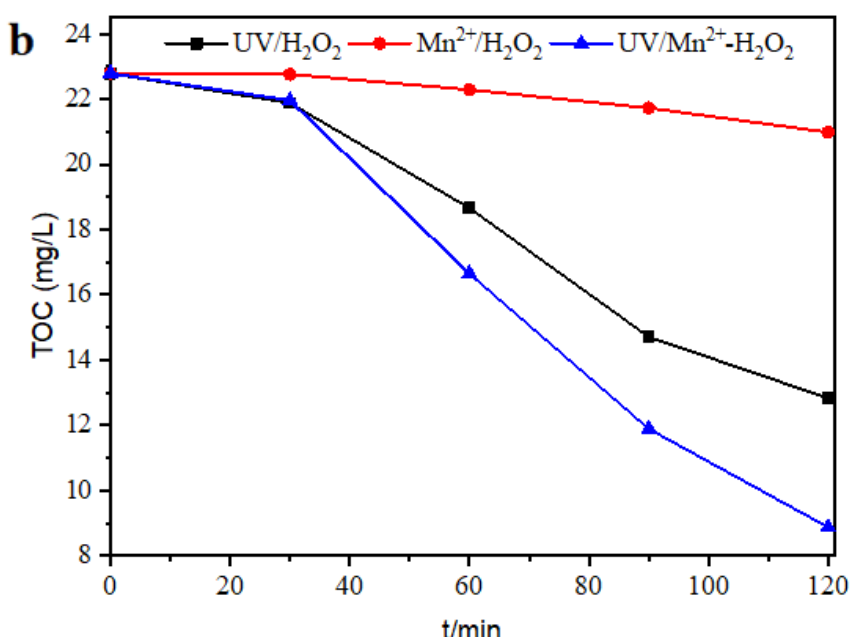

Figure 10. The removal of TN (a) and TOC (b) in different systems.

The TOC removal rate represents the degree of mineralization of the $\mathrm{X}-3 \mathrm{~B}$ solution [47]. It can be seen from Figure $10 \mathrm{~b}$ that the $\mathrm{Mn}^{2+} / \mathrm{H}_{2} \mathrm{O}_{2}$ system had almost no effect on the degradation of TOC in the X-3B solution, and the removal rate of TOC at 120 min was only $3.48 \%$, indicating that $\mathrm{Mn}^{2+} / \mathrm{H}_{2} \mathrm{O}_{2}$ system was difficult to mineralize $\mathrm{X}-3 \mathrm{~B}$. The $\mathrm{UV} / \mathrm{Mn}^{2+}$ $\mathrm{H}_{2} \mathrm{O}_{2}$ system showed the best effect on TOC removal, and obtained a TOC removal rate of $56.45 \%$ at $120 \mathrm{~min}$. It could be observed that the removal of TOC in the three systems were relatively slow at the beginning. Decolorization was completed in the early stage of the reaction, because $\cdot \mathrm{OH}$ will first attack the chromophore group of $\mathrm{X}-3 \mathrm{~B}$ and cause it to be 
cleaved, and after the decolorization was completed, the organic intermediate molecules in the solution began to be oxidized and mineralized into $\mathrm{H}_{2} \mathrm{O}$ and $\mathrm{CO}_{2}[28,48]$, leading to the quick decline of TOC.

The azo bond in X-3B is unable to maintain a steady state when exposed to light, heat, and in acidic or alkaline media, and it is prone to react, release $\mathrm{N}_{2}$, and decolorize [49]. In the UV-vis absorption spectrum of X-3B, the chromophore group is the azo bond (the conjugated $\pi$ system) corresponding to the main absorption bands at 512 and $538 \mathrm{~nm}$, and the peaks at 236, 329 and $285 \mathrm{~nm}$ in the ultraviolet region are ascribed to the aromatic rings. In the reaction process, the intensity of characteristic absorption peaks at 512 and $538 \mathrm{~nm}$ obviously reduced until they disappeared completely after $60 \mathrm{~min}$ (Figure 11), indicating that chromogenic group of X-3B had been completely cleaved. The peaks of the benzene ring in the UV range of 200-350 nm were also diminished to a certain extent, which was well in accord with TOC removal rate [50]. After 120 min degradation, the solution still had a strong terminal absorption at about $200 \mathrm{~nm}$, which may be the strong absorption of various intermediates.

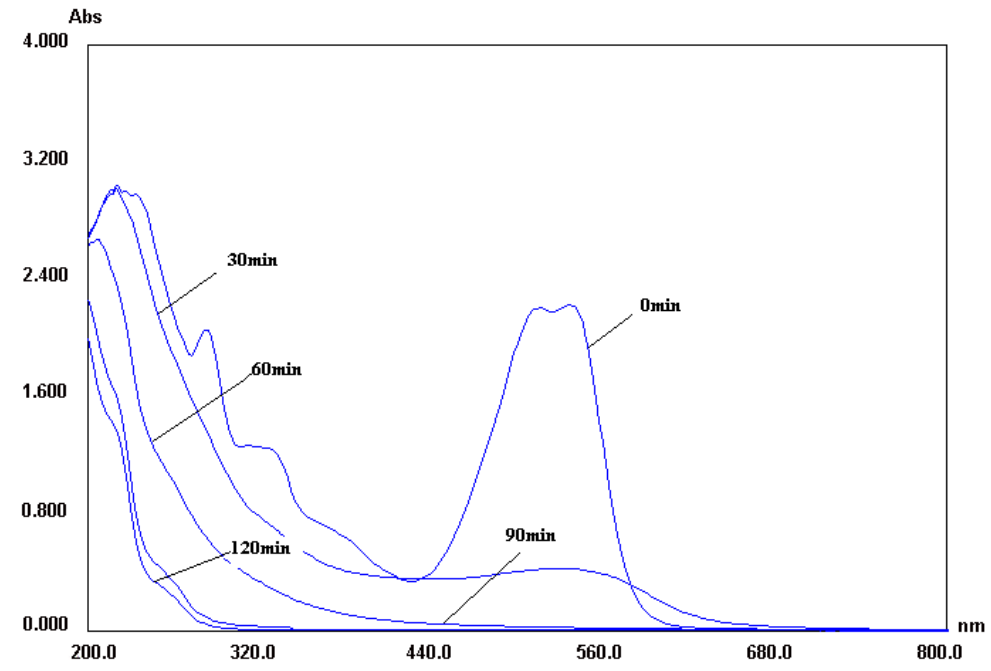

Figure 11. Change of the UV-Vis absorption spectra during the degradation of $\mathrm{X}-3 \mathrm{~B}$ by the UV/ $\mathrm{Mn}^{2+}$ $\mathrm{H}_{2} \mathrm{O}_{2}$ system.

In the comparison of ion chromatograms, the peaks of $\mathrm{Cl}^{-}, \mathrm{SO}_{4}{ }^{2-}$ and $\mathrm{NO}_{3}{ }^{-}$at $120 \mathrm{~min}$ were conspicuously higher than that at $30 \mathrm{~min}$ (Figure 12). The concentration of $\mathrm{X}-3 \mathrm{~B}$ in the experiment was $150 \mathrm{mg} / \mathrm{L}$, and its molarity was about $0.25 \mathrm{mmol} / \mathrm{L}$. According to the molecular formula of $\mathrm{X}-3 \mathrm{~B}$, theoretically, the molar concentrations of $\mathrm{Cl}, \mathrm{N}$ and $\mathrm{S}$ elements in the reaction solution were $0.5 \mathrm{mmol} / \mathrm{L}, 1.5 \mathrm{mmol} / \mathrm{L}$ and $0.5 \mathrm{mmol} / \mathrm{L}$, respectively. In addition, the initial concentration of $\mathrm{SO}_{4}{ }^{2-}$ in the catalyst used in the experiment was $0.6 \mathrm{mmol} / \mathrm{L}$. With the progress of the reaction, the concentration of $\mathrm{Cl}^{-}, \mathrm{NO}_{3}{ }^{-}$and $\mathrm{SO}_{4}{ }^{2-}$ in the solution continued to increase, indicating that the degree of oxidation was further deepened. After $60 \mathrm{~min}$, the concentration of $\mathrm{Cl}^{-}$and $\mathrm{SO}_{4}{ }^{2-}$ in the solution was relatively stable and close to the theoretical value, while $\mathrm{NO}_{3}{ }^{-}$concentration was small. When the reaction proceeded to $120 \mathrm{~min}, \mathrm{Cl}^{-}, \mathrm{NO}_{3}{ }^{-}$and $\mathrm{SO}_{4}{ }^{2-}$ concentrations were $0.4 \mathrm{mmol} / \mathrm{L}$, $0.039 \mathrm{mmol} / \mathrm{L}, 0.877 \mathrm{mmol} / \mathrm{L}$ (Figure 13). The $\mathrm{NO}_{3}{ }^{-}$in the solution may theoretically come from the azo bond, amino group and triazinyl. Nevertheless, the azo bond decomposed in the form of $\mathrm{N}_{2}$, and the triazinyl group was stable and difficult to open ring, so the $\mathrm{NO}_{3}{ }^{-}$ in the solution was mainly provided by the amino group $[51,52]$. 

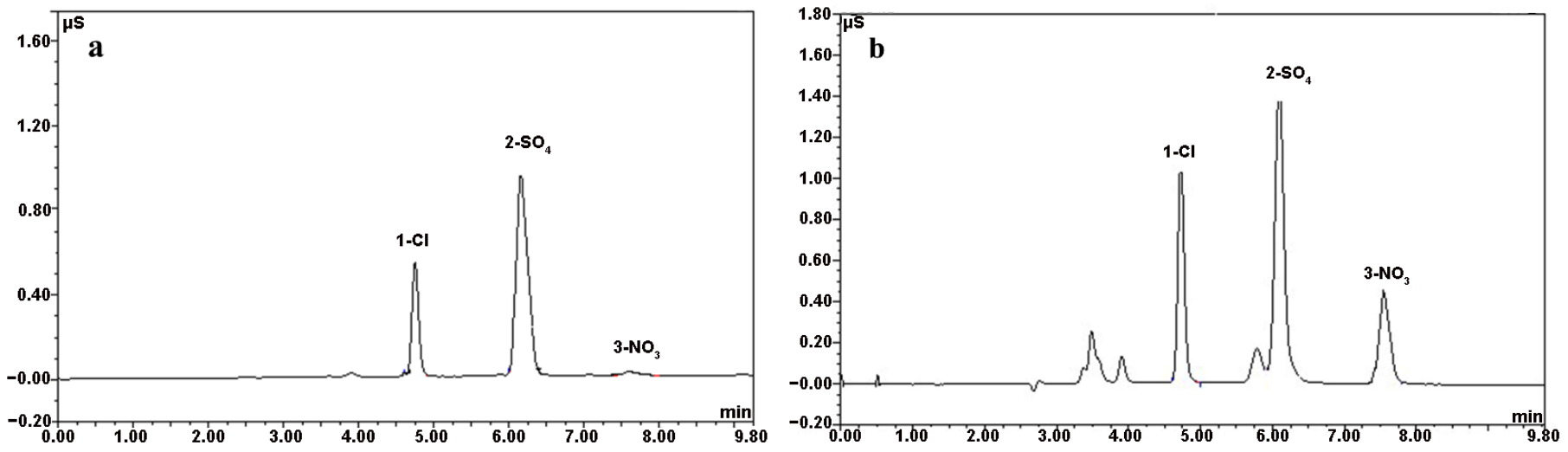

Figure 12. Ion chromatograms during the degradation of $X-3 B$ by $U V / \mathrm{Mn}^{2+}-\mathrm{H}_{2} \mathrm{O}_{2}$ system at $30 \mathrm{~min}$ (a) and $120 \mathrm{~min}(\mathbf{b})$.

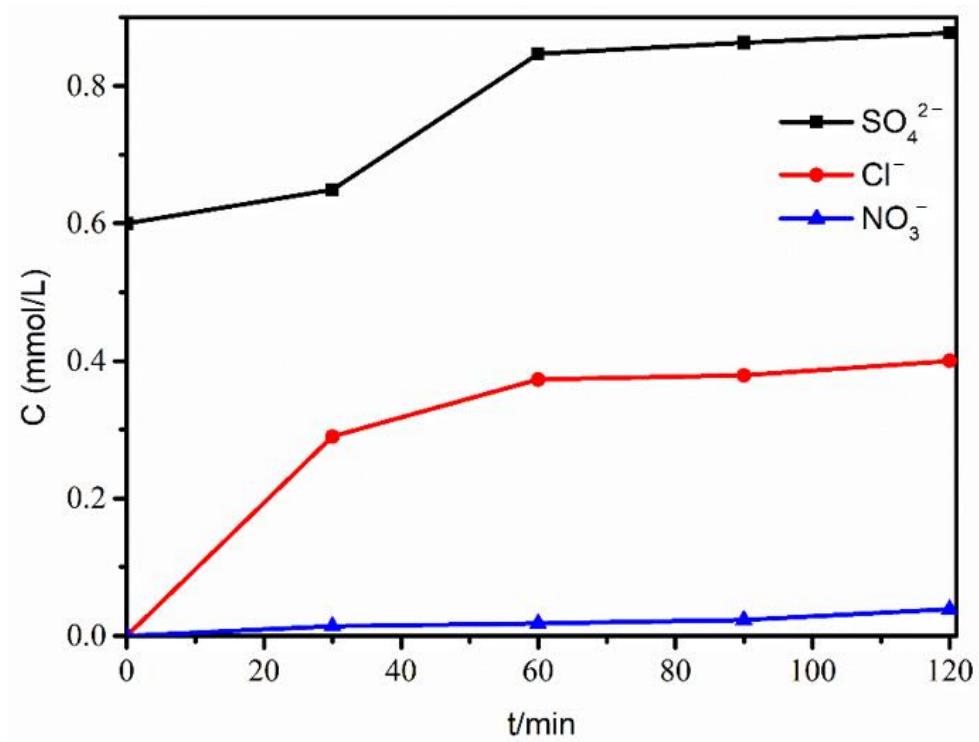

Figure 13. Change of $\mathrm{Cl}^{-}, \mathrm{NO}_{3}{ }^{-}$and $\mathrm{SO}_{4}{ }^{2-}$ concentrations during the degradation of $\mathrm{X}-3 \mathrm{~B}$ by the $\mathrm{UV} / \mathrm{Mn}^{2+}-\mathrm{H}_{2} \mathrm{O}_{2}$ system.

According to the above experimental results, combined with the structure of $\mathrm{X}-3 \mathrm{~B}$ and the previous research [52], a probable degradation pathway of X-3B in the UV $/ \mathrm{Mn}^{2+}-\mathrm{H}_{2} \mathrm{O}_{2}$ system was proposed (Figure 14 ). The $\cdot \mathrm{OH}$ generated during the photo-Fenton-like process attacked the X-3B molecules, increased the electron cloud density of the adjacent and para positions, and the electron cloud density of the $\mathrm{N}$ in $-\mathrm{NH}-$ also enlarged due to the lone pair electrons. Therefore, it is speculated that $\cdot \mathrm{OH}$ would attack the ortho position of the $-\mathrm{OH}$ and $\mathrm{N}$ atom in $-\mathrm{NH}-$ to break the chromophore group, which is consistent with the result of the rapid decolorization of $\mathrm{X}-3 \mathrm{~B}$ in the $\mathrm{UV} / \mathrm{Mn}^{2+}-\mathrm{H}_{2} \mathrm{O}_{2}$ system. The o-hydroxybenzenediazonium salt released $\mathrm{N}_{2}$, and then was further oxidized to small molecular acids or aldehydes. At the same time, the sulfonic acid group on the naphthyl ring was broken to form $\mathrm{SO}_{4}{ }^{2-}$, and the $\mathrm{Cl}$ atom on the triazine ring was replaced by $-\mathrm{OH}$ and entered the solution to form $\mathrm{Cl}^{-}$. 


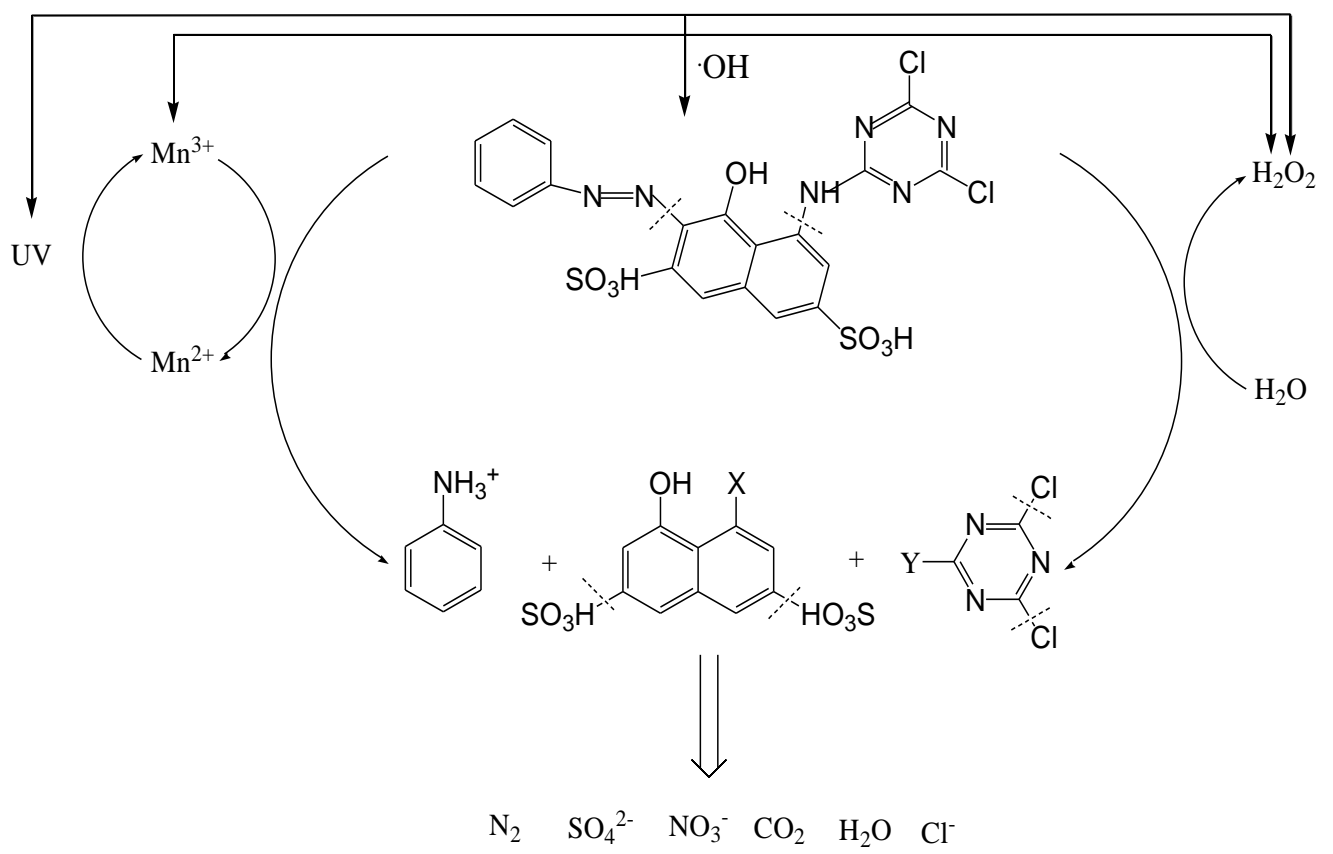

Figure 14. Probable degradation pathway of X-3B in the $\mathrm{UV} / \mathrm{Mn}^{2+}-\mathrm{H}_{2} \mathrm{O}_{2}$ system.

\section{Conclusions}

The combination of the photocatalysis with the $\mathrm{Mn}^{2+}-\mathrm{H}_{2} \mathrm{O}_{2}$ Fenton-like process was proven to have a synergetic effect on enhancing the degradation of $\mathrm{X}-3 \mathrm{~B}$, which is 2.6 times that of the combined effect of $\mathrm{Mn}^{2+} / \mathrm{H}_{2} \mathrm{O}_{2}$ and $\mathrm{UV} / \mathrm{H}_{2} \mathrm{O}_{2}$ alone. The $\mathrm{Mn}^{2+}$ had no oxidizing ability, but acted as an active catalyst in the $\mathrm{UV} / \mathrm{Mn}^{2+}-\mathrm{H}_{2} \mathrm{O}_{2}$ system, which enhanced the production of $\cdot \mathrm{OH}$ from chem-catalytic and photocatalytic decomposition of $\mathrm{H}_{2} \mathrm{O}_{2}$, and it was also an indispensable part of the whole system. The $\cdot \mathrm{OH}$ was the main contributor to decolorization of $\mathrm{X}-3 \mathrm{~B}$ and mineralization of intermediate products to inorganic substances, whose function was to attack and destroy the chromophore of $\mathrm{X}-3 \mathrm{~B}$ to rapidly decolorize. The $\cdot \mathrm{OH}$ tended to attack and break the chromophore group, and therefore, the decolorization of $\mathrm{X}-3 \mathrm{~B}$ was a relatively rapid process. In addition, various experimental conditions, such as $\mathrm{Mn}^{2+}$ and $\mathrm{H}_{2} \mathrm{O}_{2}$ concentrations, the initial solution of $\mathrm{pH}$ and the $\mathrm{X}-3 \mathrm{~B}$ initial dosage had significant influences on the degradation efficiency. The degradation of $\mathrm{X}-3 \mathrm{~B}$ reached the optimum under the conditions of $0.59 \mathrm{mmol} / \mathrm{L}$ of the $\mathrm{Mn}^{2+}, 10 \mathrm{mmol} / \mathrm{L}$ of the $\mathrm{H}_{2} \mathrm{O}_{2}, \mathrm{pH}=6$ and a high level of DO. The study opens up new ideas for the combined use of various technologies in the treatment of printing and dye wastewater, caters to the future development trend, and provides an important reference for the application conditions of this technology.

Author Contributions: G.C. planned all studies; J.W. wrote the paper; Q.L. helped plan all the studies; L.S. edited the paper; Y.Z. helped in the execution and analysis of all studies; Z.L. and C.D. helped to design the studies, edited the paper; J.F. designed all studies, edited the paper. All authors have read and agreed to the published version of the manuscript.

Funding: This work was supported by the Major Science and Technology Program for Water Pollution Control and Treatment (2012ZX07206-006), the Knowledge Innovation Program of Shenzhen (JCYJ20160526162154729), and the Engineering Research Center for Clean Production of Textile Printing and Dyeing, Ministry of Education.

Data Availability Statement: The original contributions presented in the study are included in the article files, further inquiries can be directed to the corresponding author.

Conflicts of Interest: The authors declare no conflict of interest. 


\section{References}

1. Pan, F.; Yu, Y.; Xu, A.; Xia, D.; Sun, Y.; Cai, Z.; Liu, W.; Fu, J. Application of magnetic OMS-2 in sequencing batch reactor for treating dye wastewater as a modulator of microbial community. J. Hazard. Mater. 2017, 340, 36-46. [CrossRef]

2. Samsami, S.; Mohamadi, M.; Sarrafzadeh, M.-H.; Rene, E.R.; Firoozbahr, M. Recent advances in the treatment of dye-containing wastewater from textile industries: Overview and perspectives. Process Saf. Environ. 2020, 143, 138-163. [CrossRef]

3. Lopez-Lopez, A.; Pic, J.S.; Debellefontaine, H. Ozonation of azo dye in a semi-batch reactor: A determination of the molecular and radical contributions. Chemosphere 2007, 66, 2120-2126. [CrossRef]

4. Davies, L.C.; Cabrita, G.J.M.; Ferreira, R.A.; Carias, C.C.; Novais, J.M.; Martins-Dias, S. Integrated study of the role of Phragmites australis in azo-dye treatment in a constructed wetland: From pilot to molecular scale. Ecol. Eng. 2009, 35, 961-970. [CrossRef]

5. Cai, Z.; Sun, Y.; Liu, W.; Pan, F.; Sun, P.; Fu, J. An overview of nanomaterials applied for removing dyes from wastewater. Environ. Sci. Pollut. Res. 2017, 24, 15882-15904. [CrossRef] [PubMed]

6. Wang, X.; Jia, J.; Wang, Y. Enhanced photocatalytic-electrolytic degradation of Reactive Brilliant Red X-3B in the presence of water jet cavitation. Ultrason. Sonochem. 2015, 23, 93-99. [CrossRef] [PubMed]

7. Lei, X.; Li, X.; Ruan, Z.; Zhang, T.; Pan, F.; Li, Q.; Xia, D.; Fu, J. Adsorption-photocatalytic degradation of dye pollutant in water by graphite oxide grafted titanate nanotubes. J. Mol. Liq. 2018, 266, 122-131. [CrossRef]

8. Latif, A.; Noor, S.; Sharif, Q.M.; Najeebullah, M. Different techniques recently used for the treatment of textile dyeing effluents: A review. J-Chem. Soc. Pak. 2010, 32, 115-124.

9. Katheresan, V.; Kansedo, J.; Lau, S.Y. Efficiency of various recent wastewater dye removal methods: A review. J. Environ. Chem. Eng. 2018, 6, 4676-4697. [CrossRef]

10. Lei, X.; You, M.; Pan, F.; Liu, M.; Yang, P.; Xia, D.; Li, Q.; Wang, Y.; Fu, J. CuFe $\mathrm{O}_{4} @ G O$ nanocomposite as an effective and recoverable catalyst of peroxymonosulfate activation for degradation of aqueous dye pollutants. Chin. Chem. Lett. 2019, 30, 2216-2220. [CrossRef]

11. Wang, N.; Zhu, L.; Wang, M.; Wang, D.; Tang, H. Sono-enhanced degradation of dye pollutants with the use of $\mathrm{H}_{2} \mathrm{O}_{2}$ activated by $\mathrm{Fe} 3 \mathrm{O} 4$ magnetic nanoparticles as peroxidase mimetic. Ultrason. Sonochem. 2010, 17, 78-83. [CrossRef] [PubMed]

12. Verma, A.K.; Dash, R.R.; Bhunia, P. A review on chemical coagulation/flocculation technologies for removal of colour from textile wastewaters. J. Environ. Manag. 2012, 93, 154-168. [CrossRef] [PubMed]

13. Wang, L.; Li, J. Adsorption of C.I. Reactive Red 228 dye from aqueous solution by modified cellulose from flax shive: Kinetics, equilibrium, and thermodynamics. Ind. Crop. Prod. 2013, 42, 153-158. [CrossRef]

14. Ramírez, G.; Recio, F.J.; Herrasti, P.; Ponce-de-León, C.; Sirés, I. Effect of RVC porosity on the performance of PbO 2 composite coatings with titanate nanotubes for the electrochemical oxidation of azo dyes. Electrochim. Acta 2016, 204, 9-17. [CrossRef]

15. Barragán, B.E.; Costa, C.; Carmen Márquez, M. Biodegradation of azo dyes by bacteria inoculated on solid media. Dyes Pigments 2007, 75, 73-81. [CrossRef]

16. Paździor, K.; Bilińska, L.; Ledakowicz, S. A review of the existing and emerging technologies in the combination of AOPs and biological processes in industrial textile wastewater treatment. Chem. Eng. J. 2019, 376, 120597. [CrossRef]

17. Soon, A.N.; Hameed, B.H. Degradation of Acid Blue 29 in visible light radiation using iron modified mesoporous silica as heterogeneous Photo-Fenton catalyst. Appl. Catal. A Gen. 2013, 450, 96-105. [CrossRef]

18. Ortega-Liébana, M.C.; Sánchez-López, E.; Hidalgo-Carrillo, J.; Marinas, A.; Marinas, J.M.; Urbano, F.J. A comparative study of photocatalytic degradation of 3-chloropyridine under UV and solar light by homogeneous (photo-Fenton) and heterogeneous $\left(\mathrm{TiO}_{2}\right)$ photocatalysis. Appl. Catal. B 2012, 127, 316-322. [CrossRef]

19. Silva, A.M.T.; Herney-Ramirez, J.; Söylemez, U.; Madeira, L.M. A lumped kinetic model based on the Fermi's equation applied to the catalytic wet hydrogen peroxide oxidation of Acid Orange 7. Appl. Catal. B 2012, 121-122, 10-19. [CrossRef]

20. Maroudas, A.; Pandis, P.K.; Chatzopoulou, A.; Davellas, L.-R.; Sourkouni, G.; Argirusis, C. Synergetic decolorization of azo dyes using ultrasounds, photocatalysis and photo-fenton reaction. Ultrason. Sonochem. 2021, 71, 105367. [CrossRef]

21. Perez, M.; Torrades, F.; Domenech, X. Fenton and photo-Fenton oxidation of textile effluents. Water Res. 2002, 36, 2703-2710. [CrossRef]

22. Torrades, F.; García-Montaño, J. Using central composite experimental design to optimize the degradation of real dye wastewater by Fenton and photo-Fenton reactions. Dyes Pigments 2014, 100, 184-189. [CrossRef]

23. Rios-Enriquez, M.; Shahin, N.; Durán-de-Bazúa, C.; Lang, J.; Oliveros, E.; Bossmann, S.H.; Braun, A.M. Optimization of the heterogeneous Fenton-oxidation of the model pollutant 2,4-xylidine using the optimal experimental design methodology. Sol. Energy 2004, 77, 491-501. [CrossRef]

24. Li, Y.; Sun, J.; Sun, S.P. $\mathrm{Mn}^{2+}$-mediated homogeneous Fenton-like reaction of Fe(III)-NTA complex for efficient degradation of organic contaminants under neutral conditions. J. Hazard. Mater. 2016, 313, 193-200. [CrossRef] [PubMed]

25. Wang, Y.; Liu, Y.; Xu, J. Separation of hydrogen sulfide from gas phase using $\mathrm{Ce}^{3+} / \mathrm{Mn}^{2+}$-enhanced fenton-like oxidation system. Chem. Eng. J. 2019, 359, 1486-1492. [CrossRef]

26. Pope, F.D.; Hansen, J.C.; Bayes, K.D.; Friedl, R.R.; Sander, S.P. Ultraviolet absorption spectrum of chlorine peroxide, ClOOCl. J. Phys. Chem. A 2007, 111, 4322-4332. [CrossRef]

27. Plapinger, R.E. Ultraviolet Absorption Spectra of Some Hydroxamic Acids and Hydroxamic Acid Derivatives. J. Org. Chem. 1959, 24, 802-804. [CrossRef] 
28. Li, Y.; Lu, Y.; Zhu, X. Photo-Fenton discoloration of the azo dye X-3B over pillared bentonites containing iron. J. Hazard. Mater. 2006, 132, 196-201. [CrossRef]

29. Abdo, M.S.E.; Shaban, H.; Bader, M.S.H. Decolorization by ozone of direct dyes in presence of some catalysts. J. Environ. Sci. Health Part A Environ. Sci. Eng. 2008, 23, 697-710. [CrossRef]

30. Jun, M.A.; Graham, N.J.D. Degradation of atrazine by manganese-catalysed ozonation: Influence of humic substances. Water Res. 1999, 33, 785-793.

31. Fu, J.; Chen, G.; Yang, Y.; Zhang, Z.-M.; Zeng, Q.-F.; An, S.-Q.; Zhu, H.-L. Ultraviolet irradiation combined with manganese ore catalyzed ozonation of 4-chlorophenol in aqueous solution. Water Supply 2010, 10, 97-104. [CrossRef]

32. Fu, J.; Zhang, Z.-M.; Tang, J.-Y.; Zeng, Q.-F.; An, S.-Q.; Zhu, H.-L. Photoreduction of Reactive Brilliant Red X-3B by Ultraviolet Irradiation/Potassium Borohydride/Sodium Bisulfite. J. Environ. Eng. 2010, 136, 1314-1319. [CrossRef]

33. AlHamedi, F.H.; Rauf, M.A.; Ashraf, S.S. Degradation studies of Rhodamine B in the presence of UV/ $\mathrm{H}_{2} \mathrm{O}_{2}$. Desalination 2009, 239, 159-166. [CrossRef]

34. Watts, R.J.; Sarasa, J.; Loge, F.J.; Teel, A.L. Oxidative and Reductive Pathways in Manganese-Catalyzed Fenton's Reactions. J. Environ. Eng. 2005, 131, 158-164. [CrossRef]

35. Vellanki, B.P.; Batchelor, B.; Abdel-Wahab, A. Advanced Reduction Processes: A New Class of Treatment Processes. Environ. Eng. Sci. 2013, 30, 264-271. [CrossRef]

36. Rauf, M.A.; Meetani, M.A.; Hisaindee, S. An overview on the photocatalytic degradation of azo dyes in the presence of $\mathrm{TiO}_{2}$ doped with selective transition metals. Desalination 2011, 276, 13-27. [CrossRef]

37. Ghorai, K.; Panda, A.; Bhattacharjee, M.; Mandal, D.; Hossain, A.; Bera, P.; Seikh, M.M.; Gayen, A. Facile synthesis of $\mathrm{CuCr}_{2} \mathrm{O}_{4} / \mathrm{CeO}_{2}$ nanocomposite: A new Fenton like catalyst with domestic LED light assisted improved photocatalytic activity for the degradation of RhB, MB and MO dyes. Appl. Surf. Sci. 2021, 536, 147604. [CrossRef]

38. Nikhila, M.P.; John, D.; Pai, M.R.; Renuka, N.K. Cu and Ag modified mesoporous $\mathrm{TiO}_{2}$ nanocuboids for visible light driven photocatalysis. Nano-Struct. Nano-Objects 2020, 21, 100420. [CrossRef]

39. Lin, Z.R.; Zhao, L.; Dong, Y.H. Quantitative characterization of hydroxyl radical generation in a goethite-catalyzed Fenton-like reaction. Chemosphere 2015, 141, 7-12. [CrossRef]

40. Xu, L.; Wang, J. Magnetic nanoscaled $\mathrm{Fe}_{3} \mathrm{O}_{4} / \mathrm{CeO}_{2}$ composite as an efficient Fenton-like heterogeneous catalyst for degradation of 4-chlorophenol. Environ. Sci. Technol. 2017, 46, 10145-10153. [CrossRef]

41. Hwang, S.; Huling, S.G.; Ko, S. Fenton-like degradation of MTBE: Effects of iron counter anion and radical scavengers. Chemosphere 2010, 78, 563-568. [CrossRef] [PubMed]

42. Monteagudo, J.M.; Durán, A.; San Martin, I.; Carnicer, A. Roles of different intermediate active species in the mineralization reactions of phenolic pollutants under a UV-A/C photo-Fenton process. Appl. Catal. B 2011, 11, 152. [CrossRef]

43. Fu, J.; Kyzas, G.Z.; Cai, Z.; Deliyanni, E.A.; Liu, W.; Zhao, D. Photocatalytic degradation of phenanthrene by graphite oxide-TiO ${ }_{2}$ $\mathrm{Sr}(\mathrm{OH})_{2} / \mathrm{SrCO}_{3}$ nanocomposite under solar irradiation: Effects of water quality parameters and predictive modeling. Chem. Eng. J. 2018, 335, 290-300. [CrossRef]

44. Li, M.; Qiang, Z.; Pulgarin, C.; Kiwi, J. Accelerated methylene blue (MB) degradation by Fenton reagent exposed to UV or VUV/UV light in an innovative micro photo-reactor. Appl. Catal. B 2016, 187, 83-89. [CrossRef]

45. Pirsaheb, M.; Moradi, S.; Shahlaei, M.; Wang, X.; Farhadian, N. Simultaneously implement of both weak magnetic field and aeration for ciprofloxacin removal by Fenton-like reaction. J. Environ. Manag. 2019, 246, 776-784. [CrossRef]

46. Yang, X.; Warren, R.; He, Y.; Ye, J.; Li, Q.; Wang, G. Impacts of climate change on TN load and its control in a River Basin with complex pollution sources. Sci. Total Environ. 2018, 615, 1155-1163. [CrossRef]

47. Yang, H.; Graham, N.J.D.; Wang, W.; Liu, M.; Yu, W. Evaluating and Improving the Reliability of the UV-Persulfate Method for the Determination of TOC/DOC in Surface Waters. Water Res. 2021, 196, 116918. [CrossRef]

48. Tee, H.C.; Lim, P.E.; Seng, C.E.; Mohd Nawi, M.A.; Adnan, R. Enhancement of azo dye Acid Orange 7 removal in newly developed horizontal subsurface-flow constructed wetland. J. Environ. Manag. 2015, 147, 349-355. [CrossRef]

49. Ruan, X.-C.; Liu, M.-Y.; Zeng, Q.-F.; Ding, Y.-H. Degradation and decolorization of reactive red X-3B aqueous solution by ozone integrated with internal micro-electrolysis. Sep. Purif. Technol. 2010, 74, 195-201. [CrossRef]

50. Wu, Y.; Qin, L.; Zhang, G.; Chen, L.; Guo, X.; Liu, M. Porous Solid Superacid $\mathrm{SO}_{4}{ }^{2-} / \mathrm{Fe}_{2-\mathrm{x}} \mathrm{Zr}_{\mathrm{x}} \mathrm{O}_{3}$ Fenton Catalyst for Highly Effective Oxidation of X-3B under Visible Light. Ind. Eng. Chem. Res. 2013, 52, 16698-16708. [CrossRef]

51. Hua, L.; Ma, H.; Zhang, L. Degradation process analysis of the azo dyes by catalytic wet air oxidation with catalyst $\mathrm{CuO} / \gamma-\mathrm{Al}_{2} \mathrm{O}_{3}$. Chemosphere 2013, 90, 143-149. [CrossRef] [PubMed]

52. Wang, X.Q.; Hu, X.M.; Chen, X.; Yang, J. The Study on the Reactive Brilliant Red X-3B Treatment with Internal Electrolysis-Fenton Oxidizing Method. Ind. Saf. Environ. Prot. 2010, 36, 34-35. 